economic exploitation. The author briefly discusses the land-use spectrum (from the extremes of intensive farming to national parks) as applied to the African scene. He ends with a plea for public education, which is perhaps the most important single aspect of conservation in Africa, and without which the various solutions that have been proposed are bound to fail. The book is recommended as a readable and stimulating introduction to this field.

R. M. LAWS

Elephant Gold. By P. D. Stracey. Weidenfeld and Nicolson, 30s.

I enjoyed this book, partly because its author, like myself, acquired his taste for elephants against a background of undeveloped parts of Assam. Here the jungle soon got into his blood, as earlier it had into mine, and made him feel that days spent on game-paths through wild country, and nights in grass huts with the smell of wood smoke were the only life for him. It is dedicated to the memory of A. J. W. Milroy, an apt tribute, for the text deals much with his constant zeal aimed at cleaner captives and more humane handling. Few of the great catchers, from Sanderson onwards, who have devised or improved the various methods of capture, can claim an influence on the work equal to Milroy's.

The author has amassed many miscellaneous facts about elephants and the book is partly a sort of treatise on catching throughout the world-even touching on the Belgians' work in the Congo, and partly his own first-hand khedda experiences in Assam : there is little doubt which most readers will find the more attractive- and the more useful. It is, nevertheless, most readable, not too technical and well illustrated with photographs from Assam and Mysore, the areas he knew best.

E. O. SHEBBEARE

\title{
On Safari, The Story of My Life. By Armand Denis. Collins, 25s.
}

Well-known traveller, film photographer and broadcaster, the author is a self-avowed vagrant who has always been more interested in travel than study. Having sampled seriously various "white collar" vocations with little enthusiasm-at one time having even been a prospective monk-he decided that overseas adventure was the only life for him. Concentrating his energies on the photography of all manner of interesting peoples-amongst them the pygmies of Africa-and wild animals, he makes no secret of his high ambitions, and undoubtedly his unbounded self-confidence ensured success. Soon aware of the disturbing effects of "progress," he realised from the outset that the cultural richness of some of his subjects was already doomed, and having now witnessed thirty years' disastrous destruction of wild life he makes the (not idle) prophesy that in another thirty years much of what he has described will be a thing of the past.

Armand's wanderings have taken him to a diversity of countries. Besides filming, his activities have extended to chimpanzee farming and large-scale gorilla catching - not a pleasing undertaking, more especially as all thirty of the juveniles captured died of a mysterious disease before they could be shipped from Africa. There are too, thrilling tales of encounters with crocodiles and other dangerous animals, of the catching by hand of lusty young African elephants, of lassoing the black rhinoceros, and of the capture of that elusive, equatorial forest species, the okapi. There are excellent blackand-white illustrations, one of which prompts the thought "How stupid can a lion look ?" The answer will be found facing page 144. 